which had not been so treated, but had simply been left undis. turbed in the apparatus. The positive quality thus produced by the hydrogen diminishes gradually, and becomes insensible after two or three days.]

P.S.-On December 24, 1880, one of two platinum plates in the Volta-condenser was taken out; placed in dried oxygen gas for forty-five minutes ; taken out, carried by hand, and replaced in the Volta-condenser at $\mathbf{1 2 . 3 0}$ on that day. It was then found to be negative to the platinum plate, which had been left undisturbed. The amount of the difference was about 33 of a volt. The plates were left undisturbed for seventeen minutes in the condenser; and were then tested again, and the difference was found to have fallen to 29 of a volt. At noon on the 25th they were again tested, and the difference found to be -18. The differences had been tested from time to time since that day, the plates having been left in the condenser undisturbed in the intervals. The following Table shows the whole series of these results :-

Time.

Electric difference between surfaces of a platinum plate in natural condition, and a platinum plate after 45 minutes' exposure to dry oxygen gas.

Dec. 24, I2.30 p.m. 33 of a volt. 24, 12.47 p.m 25 , noon ... 27 , noon $\ldots$ 28 , I 1.20 a.m. $3 \mathrm{I}$, noon

Jan. 4, II.0 a.m. I I, I I.40 a.m. 29 , 18 , 116 097$$
047
$$$$
\text { ... } 042
$$$$
\mathrm{O} 20
$$

,

, ",

Mr. Rennie, by whom these experiments were made during the recent Christmas holidays, had previously experimented on a platinum plate which had been made the positive pole in an electrolytic cell with an electromotive force of one volt, tending to decompose water acidulated with sulphuric acid; the other pole being a piece of platinum wire. After the plate had been one hour under this influence in the electrolytic cell he removed it, and dried it by lightly rubbing it with a piece of linen cloth. He then placed it in the Volta-condenser, and found it to be negative to a platinum plate in ordinary condition; the difference observed was 27 of a volt. This experiment was made on October $2 \mathbf{I}$; and on November 8 it was found that the difference had fallen from $\cdot 27$ to 07 . Mr. Rennie also made similar experiments with the platinum disk made the negative pole in an electrolytic cell, and found that this rendered the platinum positive to undisturbed platinum to a degree equal to about $\mathrm{O}$ of a volt. The effect of soaking the platinum plate in dry hydrogen gas, alluded to in my first postscript, which also was observed by Mr. Rennie, was found to be about 'II of a volt. Thus in the case of polarisation by hydrogen, as well as in the case of polarisation by oxygen, the effect of exposure to the dry gas was considerably greater than the effect of electro-plating the platinum with the gas by the electromotive force of one volt.

\section{THE NAVAL ARCHITECTS}

\section{$\mathrm{T}$}

$\mathrm{E}$ session of the Institution of Naval Architects just con cluded was remarkable for the number of papers on the use of steel both for shipbuilding and marine engineering. This was perhaps to be expected in consequence of the commotion among steel-users caused by the total failure of the steel plates supplied for the boilers of the Russian yacht Livadia. Accordingly we find four papers on this subject. The first, by $\mathrm{Mr}$. Samuda, deals with the effect which the introduction of steel hulls and steel-faced armour has had upon the design of ships of war. This paper is based upon the results attained by the author with a steel corvette which he has recently constructed for the Argentine Government. The dimensions of this vessel as actually constructed, and the corresponding dimensions which must of necessity have been adopted, had the material of construction been iron instead of steel, should be carefully noted in order to appreciate the true benefits to be derived from the use of the latter material.

The vessel as actually constructed is 240 feet long by 50 feet wide ; the displacement is 4200 tons, the power 4500 horses, and the coal-supply 650 tons, which is sufficient to allow her to steam 6000 miles at a speed of $8 \mathrm{knots}$, or 4300 miles at a speed of 10 knots. The speed which it is expected will be attained on the measured mile is $13^{\frac{3}{4}}$ knots. If the vessel had been built of iron and cased with iron armour, the speed and shot-resisting power remaining the same, the dimensions would have been as follows :-Length, 260 feet; breadth, 55 feet; displacement, 5200 tons; power, 5000 horses ; and coal-supply, 720 tons. This example is a very good illustration of the great benefit which naval architects will derive from the use of steel, a benefit, be it remarked, which comes most opportunely in these days of powerful ordnance; for not only has the steel-faced armour about 25 per cent. more resisting power than an equal thickness of iron, but also the weight saved in the hull and machinery by the use of steel enables a greater quantity of armour to be carried.

The second paper on steel was by Mr. W. Parker, Chief Engineer Surveyor to Lloyd's Registry, "On the Causes of the Failure of the Steel Plates supplied for the Boilers of the Livadia." Steel, as is well known, had formerly a bad reputation for treachery and uncertainty of behaviour. Latterly however a more intimate knowledge of the methods of manufacture and a better acquaintance with the processes of working had apparently quite removed this impediment to its general introduction. The failure therefore above referred to came as a surprise to shipbuilders, and the circumstances demanded and received a most searching inquiry at the hands of the engineer officers of Lloyd's. It was found that samples cut from the broken plates fulfilled every test demanded by Lloyd's, the Admiralty, and the Board of Trade. The tensile strength proved to vary between the very narrow limits of $26 \cdot \mathrm{r}$ and $28 \cdot 3$ tons per square inch. The elongation after fracture of samples 8 inches in length ranged from $27^{\circ} 3$ to $34^{\circ} 3$ per cent. Nevertheless in spite of the apparently excellent quality of the plates, it was found that after they had been punched and worked into place they had become so brittle as to be unable to stand the hydraulic proofs to which it is usual to subject boilers, and in some instances even, the plates cracked before the hydraulic test was applied. The further investigations of $\mathrm{Mr}$. Parker proved that whenever samples of the plates were punched, the material became so brittle as to break into pieces under the blow of an ordinary sledge-hammer; the tensile strength dropped to 18.4 tons per square inch, and the extensibility disappeared altogether.

Specimens were next subjected to chemical analysis, with the result of proving that, the material was from the chemical point of view far from homogeneous. A portion of the plates, about 8 inches long by 4 inches wide, was carefully freed from rust by grinding, and successive layers were planed off from one side to the other. Each layer was one-sixteenth of an inch in thickness, and they were numbered in succession as they were planed off. The result of analysis showed that the quantities of carbon, manganese, sulphur, and phosphorus varied in an extraordinary digree. These differences in the chemical composition, however, did not satisfactorily account for the behaviour of the metal. It was not till the appearance of the fractures suggested, that the material had not been properly worked under the hammer and rolls, that a really satisfactory solution of the mystery was arrived at. "A piece cut from the fractured plate was raised to a red heat and rolled to half its original thickness. Strips were then cut from this $\frac{3}{8}$.inch plate, and punched with holes $\frac{1}{2}$ inch diameter, being one half the size of those in the $\frac{8}{4}$-inch plate. This extra work on the material seemed to raise its ductility appreciably, the strips being found to bend well after punching, several of them bending to right angles, and only one of them breaking short off, while none of them showed such extraordinary signs of brittleness as were observable in the material when of the original thickness. Three pieces tested for tensile strength after rolling broke under a stress of 33 tons, $34^{\prime 25}$ tons, and $32^{\prime} 3$ tons per square inch respectively, with an elongation in 8 inches of 12 per cent., II 25 per cent., and 17.5 per cent. respectively, the last-mentioned specimen being annealed."

Mr. Parker concludes his paper by expressing the hope that the facts which he was able to lay before the meeting will tend to allay alarm and to strengthen confidence in the use of mild steel for constructive purposes. When it is considered what an enormous quantity of this material is now being used in the construction of marine boilers, as well as for the hulls of vessels, this wish will be heartily re-echoed. In the spring of 1878 there were only two marine boilers of the modern form made of mild steel in existence. Within twelve months subsequently to that date 120 steamers had been fitted with boilers of this material, and during the same period in the following year 280 vessels more. At the present moment there are no less than $x$ IOO steel boilers in use in steamships, weighing together $n v^{a r}$ 7, 000 tons. 
The third paper on steel was by Mr. J. R. Ravenhill, and gave an account of the improvements which have recently been made in mild steel castings. Many portions of machinery and steam-engines which till quite recently were invariably made of cast iron can now be formed of cast steel, with the attendant advantages of gain in strength and saving in weight.

Perhaps the most interesting paper of the four was that by M. Berrier Fontaine, the eminent French naval architect, "On the Use of Mild Steel for the Construction of the Hulls of Ships in the French Navy." The French were undoubtedly the first to introduce this material into the national navy; but though their experience of it is longer than our own, they do not seem to have acquired the same confidence in its use which is now felt in this country. For instance, we are in the habit of constructing the entire hulls of ships, incluaing the below-water plating, of steel; the French, on the other hand, continue to use iron for all work which has to be exposed to the action of sea water. The reason advanced is that they find that steel when immersed in salt water corrodes with far greater rapidity than iron. M. Berrier Fontaine quotes as examples two gunboats, the Ekee and the Tromblon, the hulls of which, completely steel-plated, have both given proof of rapid and deep corrosion. "The Tromblon was launched at Toulon on January 20, 1875, and remained afloat till October 27 of the same year. During that period of nine months it was found necessary to dock her three times, that it is to say, about every two months to ipaint the hull, the plates being rapidly and deeply attacked, especially in the neighbourhood of the waterline. The progress of this corrosion went on with such unusual rapidity, that when the time came to pass the Tromblon into the reserve it was thought necessary to haul her on to a slip instead of keeping her afloat." The whole subject of the corrosion of steel plates is at present involved in great mystery, and no two authorities seem able to agree about the cause. In the English Admiralty it is commonly believed that it is due to the presence on the surface of the plates of portions of black oxide, which constitute with the steel so many active galvanic couples, which of course rapidly promote corrosion, and hence great care is now taken to remove all traces of this oxide before the plates are coated. Whatever may be the cause, it is perfectly certain that the experience of English builders does not tally with that of M. Berrier Fontaine in this particular. Certain cases of corrosion have no doubt occurred in this country, and the hull of the Iris is an example in point; but as far as present experience goes such cases are the exception instead of the rule.

M. Berrier Fontaine gives an interesting account of the tools and other plant used in the French dockyards for the working of steel. He describes also the early difficulties which the workmen experienced, all of which have been successfully overcome. As regards the process of manufacture adopted in France, it appears that equally good results are obtained from the Bessemer and the Siemens methods, so much so that when contracts are given out it is never specified that the material is to be prepared by either of the two processes. In some works the Siemens system is employed for the superior sorts of steel, and the Bessemer process reserved for inferior descriptions, such as rails, while in other works exactly the opposite takes place. In this country, on the contrary, it is almost universally the rule to specify the Siemens process for the production of mild steel plates for ship-building and for boiler purposes.

\section{DUNES AND MOVING SANDS}

IN a communication made to the Russian Society of Naturalists, M. Sokoloff has given a description of the dunes which are seen close by Sestroryetsk, at the eastern end of the Gulf of Finland. The whole of the isthmus between the Gulf and the basin of Sestroryetsk is covered with dunes which have a double origin. Those which are close by the sea-shore are old shore-ridges, mostly covered with vegetation, parallel to one another, and having each the form of a straight line, while those which are situated more east are true dunes, built up of sand driven by the wind. They have the direction north and south, and they reach the height of a hundred feet. Several of them are quite covered with pine-forests and with moss, while others are almost quite naked. The latter are constantly brought into motion by the west wind, and south of the Sestra River a high dune will shortly cover the houses of the working men of the Sestroryetsk manufactory. This dune, about 700 feet broad, has already covered several houses, and it is always advancing further, forming smaller parallel dunes fifteen feet high; its western side is covered with numerous excavations, from which the wind has taken the sand to move it further east. M. Sokoloff, while agreeing with the well-known classification of dunes established by the explorer of Sahara, M. Vatonne, thinks that the dunes of the deserts, which owe their origin to the action of wind, might be very easily distinguished from the mostly lower ridges which appear on the sea-shores under the influence of waves, these last usually having the form of straight lines, whilst the true dunes always have a semicircular form. M. Severtzoff observed after this communication that in the steppe of Kyzylkoum, true dunes often have the same form of parallel, quite straight ridges. However, having at their origin a circular form which is so characteristic of the barkhans of the steppe, they lose by and by this form, and several smaller dunes, uniting together at their ends, take the form of a long straight ridge perpendicular to the prevailing direction of wind. M. Moushketoff, who has made a close acquaintance with the sands of Central Asia, observed that these sands, which are all sporadic, being spread among older formations, are very different as to their extent, their stratigraphical and petrographical characters, and their origin. They might be subtivided into three different classes :-I. Those which have a marine origin and which might be observed on the south-eastern shores of Lake Aral, and especially in the Kara-koum steppe. They are about 250 yards and 70 feet high, and mostly parallel to the shore. They are typical marine dunes, but their extension closely depends upon the extension of the Aralo-Caspian formation, the fossils of which are always found broken in these sands. 2. The fluvial dunes, which are very common in the valleys of the Amou, Syr, Sourkhan, and others; their height rarely exceeds ro to fifteen feet, and their length is from roo to 150 feet ; their sand is steelgray, and contains gypsum and clay. 3. The barkhans are subaerial formations; they prevail in the central part of the steppe Kyzyl-koum, but are rather rare in the Kara-koum steppe. They have the form of a sickle, and are somewhat conical, their maximum height being as much as 20 to 30 feet; their slopes are very different, that which is under the influence of the wind having an inclination from 5 to I3 degrees, whilst the other slope is short and steep, the inclination reaching sometimes as much as 43 degrees; they consist of a dirty-yellow or red sand, owing to their origin in the Tertiary sandstone, or sometimes in other harder rocks, as for instance, in the valley of the Ili River. Sometimes typical barkhans are met with among dunes, being a secondary formation arising out of the marine dunes. As to the plantations of trees on dunes, $M$. Moushketoff thinks that it would be far more rational first to determine whence the sand is brought by the wind, and to make the plantations of trees or bushes, according to the chemical character of the sand on this place, instead of making them on the dunes themselves.

\section{UNIVERSITY AND EDUCATIONAL INTELLIGENCE}

MANChester.-We learn that the Council of the Owens College proposes shortly to establish an independent Chair of Applied Mathematics.

EDINBURGH.-The tercentenary of the University of Edin. burgh will be celebrated in 1883 . The senatus are to invite representatives from other universities to be present; they also propose to bring out a history of the University during the first 300 years.

THE winter session of the College of Agriculture, Downton, Salisbury, was brought to a close on Wednesday, when the prizes were presented by Earl Nelson, who dwelt at considerable length on the present state and future prospects of British agriculture, taking a very hopeful view of the latter. The High Sheriff of Wilts warmly advocated such a combination of science with practice as was in vogue at the College. The Scholarship offered for competition amongst students who have completed their first year at the College was aw arded to Mr. Louis Johnstone, son of Sir Harcourt Johnstone, Bart., Hockurss Hall, Scarborough, the Hon. Victor A. N. Hood proxime accessit.

\section{SOCIETIES AND ACADEMIES LONDON}

Royal Society, March 31.-" Permanent Molecular Torsion of Conducting Wires produced by the Passage of an Electric Current," by Prof. D. E. Hughes, F.R.S. 